\title{
The Book Loving Atmosphere from the Campus — from Class Study Group to Parent Study Group
}

Shu-man Pan

Library Director, National Feng Yuan Senior High School

In order to build a book loving campus, National Feng Yuan Senior High School has organized many reading programs. In these programs, we divide teachers, students and their parents into several study groups. After numerous meetings, it is found that with well-planned guidance, these reading programs help them not only actively to participate in group discussion and exchange ideas but also to broaden their horizons and develop multiculturalism.

This paper intends to share our experience and strategies in the implementation of the whole reading programs. The first section is a detailed introduction to the procedures of the reading programs, including how to organize study groups, train the study group leaders, help students make reports and performances, hold contests and publish students' results. In the second section, the actual operation of parent study group is described. At the end, we examine all the achievements from these activities, and make some recommendations. In addition, we are firmly convinced that schools, families, and the society are an undivided union. If we can incorporate community resources into reading programs, we can surely create a well-structured and comfortable reading environment. We provide this experience of building a book loving campus to the public, and sincerely hope to eliminate the stereotyped image of reading and make vivid and interesting reading experiences blended into daily lives that everyone can enjoy.

\section{The Background of Establishment of Class Study Group of National Feng Yuan Senior High School}

\section{Development of life-long learning}

The rapid development of digital technology not only promotes the knowledge economy but also changes the ways of knowledge spread and accumulation. To meet transitions of time, we are encountering the rising tendency of educational reforms. In the past years, educational authorities at different levels reconsider the possibility of various types of educational activities, which leads to different educational reform schemes, bringing significant impact on education at schools. The purpose of education is no longer focusing on the instruction of knowledge. Instead, it now emphasizes on diversified values and implementation of life-long learning.

\section{Establishment of national educational policies}

In 1998, the then Minister of Education, Lin Qin-jiang, announced "White Paper of Moving into A Learning Society" and made 1998 the Year of Life-Long Learning of the R.O.C. 
There are fourteen schemes in the White Paper. The fifth one is to promote study group activities in combination with libraries. It would be started with public library system to promote study groups within the service areas and leader training. School libraries come next. Study groups would be established at each department or school. Council for Cultural Affairs held national book fairs in Taipei, Taichung and Kaohsiung, etc. in attempt to root the concept of book loving atmosphere island-wide through symposiums, observation and exchange.

\section{Implementation of study group promotion plan}

Upon taking the office, the previous Minister of Education, Zeng Zhi-lang, also endeavoured to promote learning of all people. He aggressively promoted activities of children reading and, on 25 July 2000, announced the "Implementation Program of Promotion of Study Groups for Children in Taiwan” for three years (August 2000 to August 2003). Later, Ministry of Education extended the activity to (vocational) high schools and announced "Implementation Program of Promotion of Study Groups at High Schools" on 3 August 2003 to request each school to establish concrete plans to duly hold "class study group" activities. Under the implementation of this activity, Ministry of Education gave some bookcases and books to certain classes.

\section{The aggressiveness administration of National Feng Yuan Senior High School}

National Feng Yuan Senior High School has always been focusing on the fostering of humanistic spirit while the goal of its library is to promote life-long learning. The School has been particularly aggressive in this program of the Ministry of Education. We hope to promote the atmosphere of reading through various kinds of activities to build a book loving campus. In the meantime, with combination of community resources, we aim to promote the cultural level of the community to reach the goal of life-long learning for everyone.

\section{The Concrete Measures of National Feng Yuan Senior High School to Promote “Class Study Groups" \\ 1. Establishment of project organization}

(1) Upon receipt of the program announced by the Ministry of Education, the School immediately established "Committee of Class Study Group Promotion" with the Principal as the Chairperson, Chief of the Library as the Executive Secretary, and executives of departments, divisions and teacher representatives as committee members. The class teachers worked as instructors to be responsible for promotion of class study group matters.

(2) Starting from September 2000, each freshman class established the "class study group" organization. Each class has a Study Group Chairperson, Section of Book and Section Chief of General Affairs to help promotion of reading in class.

(3) Thanks to the good implementation results, the activity was promoted in the all classes of second and third grades. 


\section{Defining reading materials}

(1) Each class may select proper themes from the Library or other learning resources (including books, audio books, films, CD ROMs, newspapers, magazines, electronic media and the Internet, etc) as the study or discussion materials for the study group.

(2) We negotiated with teachers of each course to prepare themes related to teaching and request the students to collect information, analyze, discuss and arrange the materials, followed by reading reports.

\section{Training activities}

(1) Each department held teaching symposiums to prepare themes for students to explore study and discuss. We also invite enthusiastic teachers to participate in leadership study groups outside the School.

(2) The Library held different activities to promote and foster reading habits. The activities include book fairs, theme book display, introduction to new books, lectures, films and training of seed members of class study groups.

(3) The Library provided its collection and actively negotiated with each subject area.

\section{Encourage of discussions}

(1) Each "Class Study Group" had to determine a study theme in advance and divide the entire class into groups to collect, arrange and analyze information respectively so that students develop the habit to read extracurricular books. They had to discuss and give their comments. In this way of study and mutual discussion, students could enhance and stimulate the organization, expression and creative thinking ability.

(2) During each study discussion, teachers were present and gave comments. In addition to encouraging students to fully discuss and share what they learned, students could clarify the concepts and increase the learning experiences as a result.

(3) Study discussion was held no less than twice a semester and recapitulation was completed in time. The recapitulation includes discussion time, place, reading material introduction, reports on what has been studied and teachers' comments, etc.

\section{Enhancement of relative measures}

(1) "Class Bookcases" were available at each class of the first and second grades. Besides accommodating books given by the Ministry of Education, teachers and students could add books, too. During the promotion, there were three major book resources - books from students to be recommended to classmates, good books provided by teachers and books from social resources.

(2) With the teaching materials and contents, and study themes selected, teachers recommended good extracurricular books for students to read during summer/winter vacations and write reports on what they read to be submitted to teachers when School 
began.

(3) We periodically held competition on reports on what has been studied. Good works were selected for public praise and rewards. In the meantime, the selected works were compiled into a study group collection where students could publish their reports after reading.

(4) Exclusive website for class study groups was built on which one can find policies, activities, extracurricular books, reports after reading, discussions and exchange of study groups.

(5) A copy of "Reading Passport" is handed to each student to record the books and materials read as well as their reflections on the reading.

\section{Adjustment and correction}

(1) The "Implementation Program of Promotion of Class Study Groups" announced in August 2000 is an activity started by schools selecting classes to hold "class study groups" to be promoted to all classes of the first and second grades in two years. It has been four years since the announcement and the School has not only "class study groups" in all classes of the first and second grades. Some classes of the third grades could join after voting at class meetings. What is rare is that save for continuous study and discussions on each study theme at teaching study symposiums at school, the PTA also requested to establish Parent Study Group. Therefore, the members of study groups are being adjusted and the number is increasing. Students, teachers and parents have their individual study groups. Under the horizontal contact, the seemingly independent discussions have close connection.

(2) In the use of resources, save for bookcases and books given from promotion under the program of the Ministry of Education, we have bookcases at each class from donation of PTA. The number of books is increasing at the same time with the major source of books from students and some from social resource or donation from enthusiastic people. To maximize the use of books at each class, at the end of each semester, the Library collected the books given by the Ministry of Education to each class and redistributed to other classes. That is, every freshman class student will have different books to read in each semester. In the second semester of the second grades, their books will have been exchanged four times with other classes.

(3) In material selection, students used to pick books from the classroom bookcase as their selection and appointment reading at the beginning. Later, with the popularity of electronic media and competition among classes, the reading materials are diversified to audio books, films, music and plays as their favorite.

(4) In 2002, the Ministry of Education made the review on the results of study group promotion by all (vocational) high schools in Taiwan. The School won Superiority with promotion of program, complete recapitulation of meetings and rich collection performances of each class. We were invited to participate in the "Reading Movement in 


\section{Performances of Class Study Group Promotion at National Feng Yuan Senior High School}

Since the promotion of "class study group" in 2000, it has been four years. The students participated in the groups stepped to another milestone after graduation or study at colleges, and now we have new participants. The implementation was adjusted or modified due to many factors. However, we still insist on promotion. Slowly, we see some changes at the campus that I observe:

\section{Formation of reading atmosphere}

(1) From the statistics of borrowing/returning of books at the Library each year, the borrowing rate is increasing and the usage of AV Room also escalates. One thing worth mentioning is that, after "theme study" by each department, books on natural science, encyclopedia and drama with lower borrowing rate now have different readers.

(2) The Ministry of Education gave 28-30 books to each class and each class now has around 50 books. That is, it is already very common that students bring good books to the class or classes buy books to enrich the collection.

\section{Improvement of learning and study ability}

(1) In each semester, the Library requests each class to submit no less than 10 reports after reading or on courses. The reports are submitted in compilation in the name of students or teams after mutual discussion. The Library has by now kept at least 2,100 articles.

(2) Some classes made exclusive websites for their study groups to display books in their bookcases, activities of the study groups, reports after reading, pictures of and exciting activities for exchange with other classes.

(3) During the discussion, students learnt how to find substitutes or solutions to the difficulties in the books, core issues of the conflict, compare characteristics in the books with real people around them and even rewrite the ending. The study groups are in search of new things and changes while reading has a new face.

\section{Internal mental changes}

In the study groups, students fostered their reading habits. They were not only aware that reading is the foundation of all kinds of learning and, under the increase of background knowledge, learning results are enhanced. At the same time, through the group discussions, dialogues and talks in the study groups, they improved their thinking and criticism ability and shared different experiences and values with other people as their own growth and introspection. Such free, fair and open exchanges made them feeling a sense of belonging, satisfaction, harvest and mutual sharing. This made them enjoy reading, participation, and learning. In the meantime, it helps students agree with the students, classes and the School.

\section{Diversified performances}


(1) Publication of good works

From the competition of articles, the Library invited teachers of classes to select the top three to award certificates for the yearly review. In addition to be published on the website of School Library, the top five articles will be printed into the "Collection of Superior Articles from Class Study Groups" of the School each year. Up to now, we have published four issues.

(2) Participation in national competitions

The Library also recommended the superior articles by students to participate in composition competition at the nationwide high school students' website. Each year, we boast to have students win awards with their remarkable performances.

(3) Diversified performance presentation

Learning is diversified and the content is rich. Through reading themes, students expand their learning fields continuously and guide learning competition in discussions on problems. Sources of the "study groups" are no longer from books but to "living" books of films, plays, music, museums, historical relics and experience of Mother Nature beauty. These are what students want to "read." Under several guiding instructors' arrangements, some classes tried different themes such as "reading people," reading poems," "reading illustration books," "reading objects" and "reading sceneries." At the same time, under the melodies and rhythms, students "sang books" or "played books." They rehearsed the plays or stories they read into a vivid and interesting performance with climaxes. In May 2004, the performances Snow in Mid-summer and Much Ado about Nothing are rearranged from Do Er's Bitterness of Guan Han-qin and Shakespeare's play. Save for clapping form the parents, they also won approval from the community (Please see the CD ROM "Guan Han-qin vs Shakespeare" produced by the School for the performance).

IV. Response to Class Study Groups (Establishment of Parent Study Group, current situations and future of the activities)

\section{Background of establishment of Parent Study Group}

After three years of reading activities, the most surprising is that PTA made its request - to establish a Parent Study Group. This was absolutely beyond our expectation. As a result, the Library Committee made a questionnaire (Table I) for parents to complete to further understand parents' will and needs

\section{(Table I)}




\section{Questionnaire of Class Study Group for Parents Date:}

1. Are you aware that students at the first and second grades are promoting study groups now?

$\square 1$. Yes (please continue to Q2.)

$\square 2$.No ( please continue to Q3.)

2. How did you know that the School is promoting class study groups? (Multiple choices acceptable)

$\square 1$. From your children

$\square 2$. From other parents

$\square 3$. From the website of the Library

$\square$ 4. Others: please specify

3. What do you think about the class study groups at our School?

$\square 1$. Good (please continue to Q4.)

$\square 2$. Disagree (please continue to Q5.)

4. Reasons that you agree with our "class study groups":

$\square$ 1. Children can have the habit of reading extracurricular books

$\square 2$. To increase children's knowledge

$\square 3$. To have opportunities to discuss with classmates

5. Reasons I do not agree with "class study groups:"

$\square 1$. They might influence children's schedule.

$\square 2$. They might reduce the time of children to do housework.

$\square 3$. Children might read improper books.

6. Have you discussed with your children on what they read?

$\square 1$. Yes.

$\square 2$. No

7. If time permits, would you participate in "Discussion for Parents and Children?"

$\square 1$. Yes.

⒉ No.

8. If we establish a "Parent Study Group," would you like to participate in?

$\square 1$. Yes.

$\square 2$. No.

From the questionnaires we received, we have the following responses and approval:

(1) $83 \%$ of parents were aware that the School was promoting class study groups.

(2) $68 \%$ of parents approved this activity (while some parents worried that the activity may take up the time to study).

(3) $36 \%$ of parents, if time permitted, would participate in different symposiums or parent study group.

After planning and preparation for two months, as a result, we had a parent study group for parents exclusively in September 2004. 


\section{Actual operation of parent study group}

The purpose to establish the parent study group is, in addition to increase the knowledge of parent education through reading, to bring a harmonious relationship between parents and the School through discussing and sharing after reading. We also hope parents can combine what they learn with their living experiences and put it into their lives. The items and measures of parent study group are different from those of students'. The main details are divided into three parts:

(1) Booklist: Parents buy at their own expense good books recommended and selected by the members as the regular booklist. They read at home and share with what they learn at gatherings.

(2) Lectures: We invite experts and teachers of the School to give lectures in accordance with the booklist.

(3) Talk of Life: Each member is from different environment and fields with different life experiences. Talk of Life is to encourage members to share with the valuable experiences and wisdom with others.

Between September 2004 and deadline of the article in February 2005, parent study group has read six books, held 4 lectures or symposiums. The six books are:

(1) To Appreciate Your Children / Zhou Hong; Yonghe City: Shang You, 2002

(2) Child of Beggars / Lai Dong-jin; Taipei City: Crown Culture Corporation, 2000

(3) Don't Give Me That Attitude! /Michele Borba, ed.D., translated by Xian Huei-ling, Taipei City, Commonwealth Magazine, 2004

(4) Mutant Messages Down Under / Morgan, Mavlo; translated by Lee Yong-pin. Taipei City, Triumph Publishing Co., Ltd. 1994

(5) Who Moved My Cheese? / Johnson, Spencer; translated by You Yu-zhen. Taipei City, Ollin Publishing Co., Ltd. 1999

(6) Choices / Francesco Alberoni, translated by Liu Jun- yun. Taipei City, Shin Kuan Publishing Co., Ltd. 2003

Four lectures or symposiums held:

(1) 12 September 2004 9:00-12:00 Chikung and Lives (I): spoken and demonstrated by Mr. Lin Jie-xun

(2) 19 September 2004 9:00-12:00 Chikung and Lives (II): spoken and demonstrated by Mr. Lin Jie-xun

(3) 21 October 2004 18:30-21:00 October Sky - Film and Symposium

(4) 20 January 2005 14:00-16:00 Tea in Lives by Lu Li-chuan

Afterwards, teachers also joined this adult reading group, making the reading atmosphere more popular. Members are of different ages with different occupations but the same interest - reading in this reading group of parents and teachers. The various learning themes 
started under the life experience sharing by parents and teachers. The following two things are worth mentioning:

(1) 12 September 2004: Chikung and Lives recommended by parents. In addition to one hour of lecture of home care, Mr. Lin also taught parents simple Taichi to strengthen bodies. He won a lot of clapping with attendance of 120 parents and community people who requested another lecture in the week after.

(2) Another particular event is that, Mr. Liu Jian-chen participated in our parent study group. Upon knowing that the budget to buy books was not quite enough, he requested the businesswoman Lai Yen-xue to donate a great deal of books (Table II) and give three books to each parent study group member (Table III). That was very marvelous.

(Table II)

Books Donated by Ms Lai Yen-xue to the Library

\begin{tabular}{|c|c|c|c|c|c|}
\hline Number & Name & Publisher & Target & Volumes & Remark \\
\hline 1 & 400 Years of Classical Music & Jin Xiu & General & $\begin{array}{l}16 \mathrm{~B} \\
100 \mathrm{CD} \\
\end{array}$ & \\
\hline 2 & Musical Music Maestros & $\begin{array}{l}\text { Formosan Magazine } \\
\text { Press Inc. }\end{array}$ & General & $\begin{array}{l}13 \mathrm{~B} \\
\underline{52 \mathrm{CD}} \\
\end{array}$ & \\
\hline 3 & Great Music & $\begin{array}{l}\text { Formosan Magazine } \\
\text { Press Inc. }\end{array}$ & General & $12 \mathrm{~B}$ & \\
\hline 4 & Taiwan Visual History & Li Hong & General & $6 \mathrm{~B}$ & \\
\hline 5 & Great China Encyclopedia & Min Shan Publishing & General & $16 B$ & \\
\hline 6 & \begin{tabular}{|l} 
Collection of Literature \\
Wisdom
\end{tabular} & Hua Wen Wang & General & $11 \mathrm{~B}$ & \\
\hline 7 & $\begin{array}{l}\text { Collection of e-office } \\
\text { Learning }\end{array}$ & Hua Wen Wang & General & $10 \mathrm{~B}$ & \\
\hline 8 & Formosa & $\begin{array}{l}\text { Taiwan Public Televi- } \\
\text { sion }\end{array}$ & General & $101 \mathrm{VCD}$ & \\
\hline 9 & $\begin{array}{l}\text { NHK Natural Science } \\
\text { Encyclopedia }\end{array}$ & Zuo Feng & General & $100 \mathrm{VCD}$ & \\
\hline 10 & China & Xiao Ma Ge & General & $100 \mathrm{VCD}$ & $\begin{array}{l}\text { For public } \\
\text { broad- } \\
\text { casting }\end{array}$ \\
\hline 11 & $\begin{array}{l}\text { Selections of the Great } \\
\text { People in the World }\end{array}$ & 99 Books & General & 52 DVD & \\
\hline & Total & & & & \\
\hline
\end{tabular}


(Table III) Books Donated to Parent Study Group Members by Ms Lai Yen-xue

\begin{tabular}{|l|l|l|l|l|l|}
\hline Number & Names & Publisher & Target & Volume & Remark \\
\hline 12 & $\begin{array}{l}\text { Don't Give Me That Atti- } \\
\text { tude! }\end{array}$ & $\begin{array}{l}\text { Commonwealth } \\
\text { Magazine }\end{array}$ & General & $1 \mathrm{~B}$ & \\
\hline 13 & Single Parasitism & The Journalist & General & $1 \mathrm{~B}$ & \\
\hline 14 & Choices & Shin Kuan & General & $1 \mathrm{~B}$ & \\
\hline
\end{tabular}

\section{Prospects of parent study group}

Members of parent study group participated voluntarily. They come from the same community and have the common interest of reading with the same dreams. They enjoy good relationship, share their life experiences, learn and grow together. They care about and encourage one another to stimulate their potentials and condense the cultural power of the community. Once teachers and parents promote atmosphere of reading and make friends with reading, the book loving atmosphere will be spread everywhere in the community so that community people can improve the living quality and enrich the life meanings through reading.

\section{Discovery and Prospects}

\section{Discovery in interpersonal relationships}

(1) As long as librarians concentrate on running a library, students will be attracted to use the library, which will benefit teaching and build the atmosphere at school. Once students are well taught, parents can be educated to improve community environment. The participation of parents and booming development of the community will be returned to schools, making a beneficial cycle.

(2) Promotion of reading activities. Through the reading themes, teachers can make up the insufficiency of teaching materials and increase the learning interest of students with explanations of examples and experience activities. Teachers make teaching activities more diversified and build a good relationship with students, making them more willing to cooperate, feel a sense of belonging and integrated into the class learning and life contexts. The distance between teachers/students and the environment is shortened that they can build a sustainable "new partnership." That is, the operation of class study groups provides of an alternative class strategy, which enlivens teaching as well as enhances class operation.

\section{Discovery in affair relationships}

(1) At the beginning of study group promotion, everyone was skeptic. Parents were particularly worried about the time to read extracurricular books would take up the time of their school study. After our great efforts with performances, parents gradually agreed that reading is the key to diversified wisdom and success. They were willing to join and promote the community atmosphere. With the approval, the development will be faster and faster, forming a force. This proves that things are difficult at the beginning. Once you can insist, things will turn better with a lot of fun. 
(2) The promotion of study groups increases the possibility for libraries to integrate with education and teaching of various courses. In the complicated information environment, the traditional knowledge in the classroom is no longer up to date. It cannot be ignored to teach students how to control information and reading strategies. Libraries are places where all kinds of information are gathered. Provided they can be integrated with teachers to mutually negotiate teaching units, design courses, contents, procedures and teaching information to fully develop the role of reference librarian, they will definitely provide teachers and students with diversified teaching resources, making student acquire more knowledge and reducing teachers' burden.

\section{Future prospects}

(1) We have now a variety of study groups such as class study groups, teaching study groups, parent study groups, administration study groups and psychological assistance study groups, etc. As long as we endeavor to run these groups, we will definitely build a campus with book loving atmosphere. In fact, the School can establish more community study groups for parent/children, mothers, and brides of foreign nationalities. They will promote the development of the community and exert the social teaching function of the community.

(2) In the event that a library can provide art news on the website or open the library to the public for exhibitions, it will help to create learning atmosphere for the community. With the operation of various study groups, interaction between schools and community will be promoted to reach the goal of mutual integration and a win-win situation for both parties.

\section{Conclusion}

With the example of reading activity promotion at National Feng Yuan Senior High School, I would like to let the public know that an activity in combination of participation of parents, teachers and students guided by a library systemically not only stimulates the reading interest of the participants but also helps them foster a habit of reading extracurricular books. In the meantime, we also understand that schools, families and the society are inseparable and shall be connected tightly for complementary assistance. We provide this experience of building a campus with book loving experience to the public and sincerely hope to eliminate the dull image of reading and make vivid and interesting reading experiences blended into daily lives that everyone can enjoy.

\section{Reference:}

1. Ministry of Education (1990): Implementation Program of Promotion of Class Study Groups at High Schools. Date: 3 August 2000 (89) Jiao Zhong (Si) Zhi \#89510572

2. Chen Qin-xi(2000): Concepts and Measures of Promotion of Class Study Groups at High Schools http://www.tcssh.tc.edu.tw/lib/studgrp/class/clas_inst/study_hhtm

3. http://140.111.1.22/English.home_policy.htm (see the Education System \& policy)

4. Drama CD-ROM of the School Name: Guan Han-qin vs Shakespeare"

5. Annual Statistics of Book Borrowing and Lending, Library of National Feng Yuan Senior High 
School (1996-2004)

6. Statistics Report of Questionnaires for Parent Study Group 
Reproduced with permission of the copyright owner. Further reproduction prohibited without permission. 